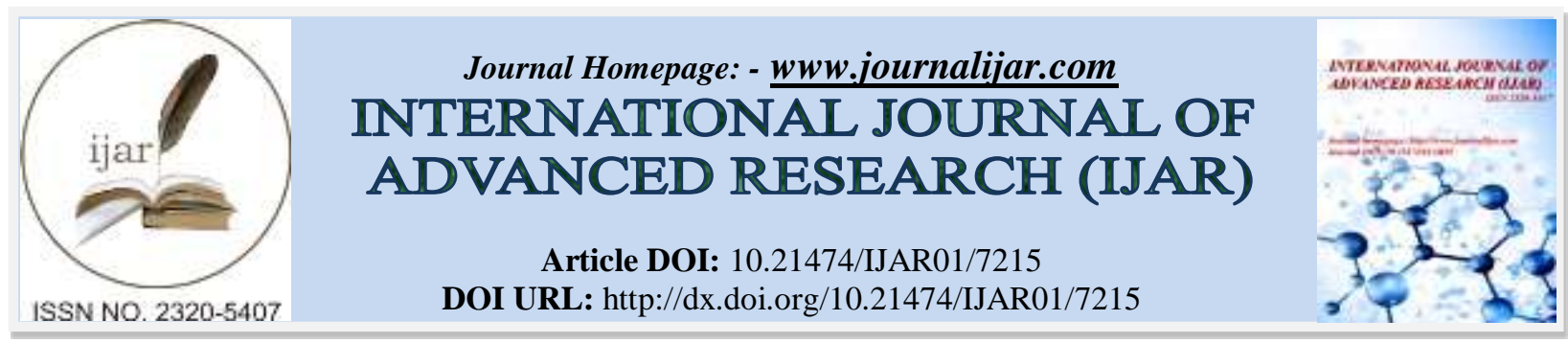

RESEARCH ARTICLE

\title{
KNOWLEDGE, ATTITUDE AND PRACTICES AMONG THE MEDICAL PRACTITIONERS IN CHENNAI REGARDING THE RELATIONSHIP BETWEEN PERIODONTAL DISEASES AND SYSTEMIC HEALTH.
}

Sai Sarath Kumar Kothimbakkam, Burnice Nalina Kumari and G B Parthasarathy and Sangeetha S.

\section{Manuscript Info}

Manuscript History

Received: 05 April 2018

Final Accepted: 07 May 2018

Published: June 2018

Keywords:-

Medical practitioners, periodontal diseases, Knowledge, Attitude,

Practices.

\section{Abstract}

Background: Periodontal diseases are associated with multiple systemic conditions of medical interest, and a large number of systemic diseases have oral manifestations. This means that physicians must play a more active role in educating their patients about the role dental disease plays in their overall health.

Aim: This study was conducted to assess the periodontal knowledge, attitude and practices among the medical practitioners in Chennai.

Study population and methodology: Cross sectional study was conducted using a structured questionnaire on 516 medical practitioners randomly selected from those registered in Indian Medical Association, Chennai city branch.

Results: Among the 516 respondents, $48.3 \%$ were male, $51.7 \%$ were female, $48 \%$ were undergraduates and $52 \%$ were postgraduates and PG diploma holders. $70 \%$ of medical practitioners had poor to fair, and $30 \%$ good and none had excellent KAP grading. The undergraduates had a better knowledge than the PG and PG diploma holders.

Conclusion: Medical professionals lack a satisfactory knowledge and attitude to periodontal health.

Copy Right, IJAR, 2018,. All rights reserved.

\section{Clinical Relevance:-}

Scientific rationale for study: The mouth is an integral part of the body which is a potential site of many infectious and inflammatory diseases. Periodontal disease has its effect on the entire body and hence it cannot be omitted from the subject of health. Thus, physicians should play a pivotal role in oral public health. There are very few studies that have collected data concerning the dental knowledge of medical practitioners in Chennai, Tamil Nadu, India.

Principal findings: this cross-sectional questionnaire survey was carried out among 516 medical practitioners in Chennai, India. The results of the study clearly demonstrate that medical practitioners have a fair knowledge, attitude and awareness about the relationship between systemic and periodontal health. The undergraduate doctors were slightly better when compared to the postgraduate and PG Diploma doctors.

Practical implications: The present study assessed the unsatisfactory views and knowledge of medical doctors on the association between periodontal disease and general health and their willingness to advise their patients to seek dental treatment. This recommends the necessity to incorporate basic knowledge about dentistry in medical syllabi, to conduct seminars and continuing education programmes to improve their knowledge about various dental diseases and their association with systemic health, to encourage medical practitioners to examine the oral cavity 
during their general examination for patients and to encourage the setting up of associate clinics for the benefit of providing medical and dental services under one roof.

\section{Introduction:-}

The oral cavity is considered to be the most unique part of the body as it contains derivatives of all the primary germinal layers, incorporates tissues which are not demonstrable anywhere else in the body, and also because of its marked role in providing many diagnostic clues to various systemic diseases. (Cheraskin E 1958, Epstein J.B 1980) William Osler described the mouth to be the mirror of the body, it acts as a gateway and a barrage of numerous invaders like bacteria, fungi, parasites and viruses. (Mehrotra V et al. 2015). Thus the oral cavity can become a niche for progression of disease affecting other parts of the body.

Dental problems are very frequently overshadowed by other health needs that are considered to be more obvious and urgent by the attending physician, also the individual patient themselves (Opeodu O.I et al. 2014). But there is now evidence on the contrary showing that oral lesions have a bearing on the systemic health and vice-versa. For example, it has been reported that periodontal disease may be an etiology of systemic diseases that impacts the overall health of the individual (Asa'Ad F et al. 2014). Periodontal diseases is associated with coronary heart diseases (Syrjänen J et al. 1989, Umino M et al. 1993, Madianos P.N. et al. 2002), increases the severity of diabetes, contributes to low pre-term birth weight (Moreu G et al. 2005), contribute to respiratory disease, interfere with proper digestion, play a role in osteoporosis, severely stress the immune system and lower the resistance to other infections. (Hämäläinen $\mathrm{P}$ et al. 2005). Therefore, periodontal diseases are associated with various systemic conditions of medical interest, on the other hand large number of systemic disorders have oral manifestations. Though medical practitioners are the prime health-care professionals, their knowledge about the relationship between periodontal health and systemic diseases which could be life threatening is scarce (Chandu G.N. et al. 2006). Hence, it is recommended that the medical practitioners should also possess basic dental knowledge to act as public health educators to uncover signs and symptoms of dental diseases in patients, and to guide them to seek appropriate management. Moreover, they have an opportunity to make a significant difference because of their access to families as a family physician.

\section{Aims and objectives:-}

Periodontal disease is not just a minor ailment of the gums and the associated supporting tissue, it is a disease of the body that happens to begin in the mouth (Patil A.V. 2010). The role that a medical practitioner can play in educating the population about the oral health promotion depends on his knowledge about the relationship between periodontal diseases and systemic health, his attitude towards oral hygiene and their routine practice to maintain oral health.

It is found that very few studies have collected data concerning the dental awareness of medical practitioners in Chennai. Hence, this cross sectional survey was undertaken to assess the knowledge in, attitude to and practical application of dental and oral diseases of medical practitioners in Chennai, Tamil Nadu, India.

\section{Methodology:-}

For conducting this cross sectional questionnaire survey, a list of medical practitioners was obtained from the Indian Medical Association, Chennai branch. There were totally 27,438 registered medical doctors in Tamil Nadu, out of which 8754 were practicing in Chennai, approximately during January 2017

The pre-tested, self-administered and structured questionnaire was developed from the literature review of relevant articles. The questionnaire consisted of two sections. The first section was related to socio-demographic data including age, sex, educational qualification and field of specialization. The second section consisted of three parts with totally 15 questions assessing the periodontal health knowledge, their attitude towards the importance of oral hygiene and importance of screening dental diseases in medical practice

A simple random sampling method was used to reach the convenient sample size. The questionnaire was distributed to 516 medical professionals who met the inclusion criteria. The medical practitioners were approached privately and informed consent was obtained after explaining the purpose of the study. It was mentioned that the identity of the participant would not be disclosed. A time frame of 15 minutes was given to fill in the questionnaire which was 
then collected immediately. The duration of the study was six months from august 2016 to January 2017. The data thus collected was compiled, analyzed and interpreted as follows.

\section{Results:-}

Characteristics of the study population:-

All of the five hundred and sixteen questionnaires were filled completely and returned, giving a response rate of $100 \%$. The age of the respondents ranged from 24 to 80 years with a mean of $35.79 \pm 13.80$ years. (Figure 1a) represents the study population based on their age group and gender. Two hundred and ninety four (57\%) were in the age range of 24-33 years, about eighty seven (16.9\%) were in the age range of 34-43 years, fifty one (9.9\%) of them were in the age range of 44-53 years, forty five (8.7\%) were in the age range of 54-63 years and thirty nine $(7.6 \%)$ were 64 years of age or older (Figure 1b). Two hundred and forty nine (48.3\%) of the respondents were males and the remaining two hundred and sixty seven $(51.7 \%)$ were females (Figure 2). (Figures 1c and 1d) represent the study population according to gender and qualification. Almost $48 \%$ were undergraduates whereas $52 \%$ were post graduates or PG diploma holders. (Figure 1e and 1f) represent the distribution of study population according to gender and specialty.

Responses of the study subjects to questions relating to their knowledge about the inter-relationship between periodontal diseases and systemic health. (Table 1):-

Among the study subjects, 207 practitioners said that they were aware of the two fold increase in the risk of infective endocarditis in patients with poor oral hygiene (Figure 2a). When asked if they were aware of the increased risk of periodontal diseases in patients with diabetes, 270 medical practitioners responded in the affirmative (Figure $2 \mathrm{~b}$ ). A mere 24 medical practitioners, were aware that periodontal diseases could result in premature rupture of membrane and pre-term, low birth-weight babies (Figure 2c). Only 9 practitioners were aware that periodontal diseases may increase the risk of eclampsia by 2 times (Figure 2d). 132 practitioners were aware that periodontal diseases were a factor in hospitalized patients contracting hospital acquired pneumonia (Figure 2e).

Responses of the study subjects to questions relating to their attitude towards dental health. (Table 2):Among the study subjects, 348 practitioners answered correctly saying that relationship between systemic diseases and oral health is a two way process (Figure 3a). When asked if they acquired any knowledge about oral diseases and their relationship with systemic health while they were in medical college, 318 medical practitioners responded in the positive (Figure 3b). 384 medical practitioners felt that medical training should also include some acquaintance about screening for oral diseases (Figure 3c).

Among the subjects, 351 medical practitioners thought that oral health evaluation should be done by general practitioners in case of systemically ill patients (Figure 3d). About 432 practitioners understood the importance of the inter-relationship between systemic and oral diseases and were using this knowledge for the welfare of the patients (Figure 3e).

Responses of the study subjects when asked about the importance of dental health in their clinical practice. (Table 3):-

Among the study subjects, only 90 practitioners always enquired from their patients if they had ever had any oral disease, whereas 321 practitioners occasionally enquired the same(Figure 4a). When asked if they referred their patients to the dentist for a dental health status checkup, 309 practitioners responded that they occasionally advised their patients to do so whereas 54 stated that they have never referred their patients to the dentist (Figure $4 \mathrm{~b}$ ).

342 medical practitioners said that they only occasionally looked for the systemic manifestations of oral diseases. In contrast 87 practitioners have never looked for or noticed the oral manifestations of systemic diseases (Figure 4c).

When asked how often they felt patients should have a dental checkup, 165 practitioners felt that a dental checkup should be done once in 6 months, on the other hand 81 practitioners felt that patients needed to visit the dentist only when they had a dental problem (Figure 4d).

264 medical practitioners have occasionally advised their patients to visit a dentist to rule out focal sepsis before any surgery, while 144 practitioners have never recommended the same before a surgery (Figure 4e). 


\section{KAP grading of the respondents:-}

Individual KAP scores were calculated. Seventy percent of the medical practitioners had poor to fair KAP grade. Only, thirty percent had a good KAP grade and none of the practitioners included had an excellent KAP grade regarding the interrelationship between the systemic and dental diseases.

\section{Discussion:-}

The mouth and the face are highly accessible parts of the body, sensitive to and able to reflect changes occurring internally. Similarly, Poor oral conditions have the ability to adversely affect general health and vice versa (Radha G et al. 2008). Recent scientific studies clearly demonstrate that physicians could and should play a pivotal role in oral public health.

This cross sectional study was conducted to assess the knowledge, attitude and practice of different medical practitioners of Chennai city relating to oral health. Results of the study showed that $70 \%$ of the medical practitioners had a fair knowledge of dental diseases affecting the general health. This result is similar to a study conducted by A Gur et al (2009), in which $90 \%$ of the respondents had a poor to fair knowledge about the interrelationship of dental and systemic health.

\section{Dental knowledge of medical practitioners:-}

In the present study, with regard to the knowledge of dental diseases, 207 (40.1\%) of the medical practitioners were aware of the increased risk of infective endocarditis in patients with poor oral hygiene. In contrast, in a study conducted by Srinidhi et al (2011) in Chennai about 83\% of the study subjects were aware of the risk association between periodontal diseases and infective endocarditis and in another study conducted by Vishal Mehrotra et al (2015) in Kanpur $84.8 \%$ of the subjects were aware of the same.

Of the 516 practitioners who took part in the study 270 practitioners $(52.3 \%)$ were aware that Diabetes increased the risk and severity of periodontal diseases. Similarly, in a study conducted by Opeodu et al (2014) 55.6\% of the medical practitioners strongly agreed that there was a relationship between diabetes and periodontal diseases, whereas in a study by Asa'ad et al (2014) a mere $10.4 \%$ of the subjects were of the link between diabetes and periodontal diseases.

When the study subjects were asked if they knew that periodontal diseases could lead to pre-term low birth-weight babies only 24 study subjects $(4.6 \%)$ of the total 516 replied in the affirmative. In comparison in a study conducted by Opeodu et al (2014), $24.2 \%$ of the subjects agreed.

Only $1.74 \%$ or 9 of the 516 study subjects were aware that periodontal diseases increase the risk of eclampsia. In contrast, a study by Opeodu et al (2014) showed that $20.8 \%$ strongly agreed to this risk association.

\section{Attitude of medical practitioners:-}

In the present study, 348 of the $512(67.4 \%)$ medical practitioners acknowledged that the relationship between systemic and oral diseases is a 2-way process. In a study by Gur et al (2009) $16 \%$ agreed that it is a 2 way process, whereas studies by Vishal Mehrotra et al (2015) and Ashok Patil et al (2010), 90\% and 92\% respectively, acknowledged that there existed a relationship between oral and general health.

318 of the medical practitioners (61.6\%) stated that they acquired some knowledge regarding oral diseases and their relationship with systemic diseases while they were in medical college, this was in stark contrast to the study by Asa'ad et al (2014) wherein only $6.8 \%$ of the study subjects said they had acquired some sort of training regarding dental lesions in medical school.

A majority of the practitioners, 351 of the $516(68 \%)$ felt that oral health evaluation should be done by general practitioners in cases of systemically ill patients. However the results were vastly more positive when compared to the study by Asa'ad (2014) wherein only $26.7 \%$ of medical practitioners felt that it was central to their role as a physician to check the oral health status. 


\section{Practices by Medical Practitioners:-}

In the present study, 321 of the 516 of medical practitioners (62.2\%) enquired from their patients of their oral health history whereas $6.3 \%$ of the medical practitioners had never enquired from their patients. The results of a study by Asa'ad et al (2014) was rather different in that $43.4 \%$ of the study subjects had enquired from their patients of their oral health and $49.8 \%$ never enquired of the same.

309 medical practitioners $(59.8 \%)$ had occasionally referred their patients to the dentist for an opinion about their oral hygiene status and $\mathbf{1 0 . 4 \%}$ had never done so, the results were similar a study by Asa'ad et al (2014) where $57.5 \%$ of the medical practitioners had occasionally refereed their patients whereas, $33 \%$ had never referred their patients to a dentist.

In our study, $31.9 \%$ of the medical practitioners a stated that they would suggest their patients to visit the dentist once in 6 months. The results in the present study are in stark contrast to studies conducted by Srinidhi et al (2011), Jagadish Chandra et al (2006) and Vishal Mehrotra et al (2015), 76.3\%, 86.3\% and 81.6\% of the study subjects respectively, advised their patients to visit dentist once in 6 months.

Results of the study showed that the medical practitioners had poor to fair knowledge about dentistry. Ashok Patil et al (2010) concluded in his study that medical practitioners had a poor level of oral awareness whereas Gur et al (2009) in his study concluded that $90 \%$ of the respondents had poor to fair knowledge. Based on their qualifications undergraduate doctors had better KAP grading than their PG and PG Diploma counterparts

\section{Conclusion:-}

From the current study it can be concluded that medical professionals, on a whole, lack a satisfactory knowledge and attitude to oral health. In this study it was noted that the undergraduates had better knowledge, attitude and practical application compared to the postgraduates and PG diploma subjects. This may be because the undergraduate medical practitioners are exposed to a greater variety of patients and diseases irrespective of the specialties, thus they may have a more encompassing view of the relationship between oral and general health. Since the postgraduates are highly expertised in a particular field their view of health is much narrower compared to the undergraduates and pertains to the field of expertise. It is incumbent that medical practitioners keep their knowledge updated and active part in maintaining overall health of the patient.

Table 1:- Responses of study subjects based on their dental knowledge

\begin{tabular}{|c|c|c|c|c|c|c|c|}
\hline \multirow{2}{*}{$\begin{array}{l}\text { Questions On Dental } \\
\text { Knowledge }\end{array}$} & \multirow[t]{2}{*}{ Responses } & \multicolumn{5}{|l|}{ Specialities } & \multirow[t]{2}{*}{ Total } \\
\hline & & Diabetologist & Gynaecologist & Cardiologist & Others & None & \\
\hline \multirow{3}{*}{$\begin{array}{l}\text { Patients with poor oral } \\
\text { hygiene has two folds } \\
\text { increased risk of } \\
\text { infective endocarditis }\end{array}$} & Aware & $18(3.4 \%)$ & $6(1.1 \%)$ & $12(2.3 \%)$ & $45(8.7 \%)$ & $126(24.4 \%)$ & $207(40.1 \%)$ \\
\hline & Unaware & $15(2.9 \%)$ & $21(4 \%)$ & $6(1.1 \%)$ & $42(8.1 \%)$ & $93(18 \%)$ & $177(34.3 \%)$ \\
\hline & To an extent & $15(2.9 \%)$ & $24(4.6 \%)$ & $15(2.9 \%)$ & $48(9.3 \%)$ & $30(5.8 \%)$ & $132(25.5 \%)$ \\
\hline \multirow{3}{*}{$\begin{array}{l}\text { Diabetes increases the } \\
\text { risk and severity of } \\
\text { periodontal disease }\end{array}$} & Aware & $27(5.2 \%)$ & $30(5.8 \%)$ & $24(4.6 \%)$ & $81(15.6 \%)$ & $108(20.9 \%)$ & $270(52.3 \%)$ \\
\hline & Unaware & $9(1.7 \%)$ & $12(2.3 \%)$ & $3(0.6 \%)$ & $24(4.6 \%)$ & $99(19.1 \%)$ & $147(28.4 \%)$ \\
\hline & To an extent & $12(2.3 \%)$ & $9(1.7 \%)$ & $6(1.1 \%)$ & $30(5.8 \%)$ & $42(8.1 \%)$ & $99(19.1 \%)$ \\
\hline \multirow{3}{*}{$\begin{array}{l}\text { Periodontal disease can } \\
\text { result in preterm low } \\
\text { birth weight babies }\end{array}$} & Aware & 0 & 0 & 0 & $15(2.9 \%)$ & $9(1.7 \%)$ & $24(4.6 \%)$ \\
\hline & Unaware & $36(6.9 \%)$ & $30(5.8 \%)$ & $24(4.6 \%)$ & $99(19.1 \%)$ & $186(36 \%)$ & $375(72.6 \%)$ \\
\hline & To an extent & $12(2.3 \%)$ & $21(4 \%)$ & $9(1.7 \%)$ & $21(4 \%)$ & $54(10.4 \%)$ & $117(22.7 \%)$ \\
\hline \multirow{5}{*}{$\begin{array}{l}\text { Periodontal disease may } \\
\text { increase the risk of } \\
\text { eclampsia to } 2-2.5 \text { folds }\end{array}$} & Aware & 0 & 0 & 0 & $3(0.6 \%)$ & $6(1.1 \%)$ & $9(1.7 \%)$ \\
\hline & Unaware & $33(6.3 \%)$ & $39(7.5 \%)$ & $21(4 \%)$ & $102(19.7 \%)$ & $195(37.8 \%)$ & $390(75.5 \%)$ \\
\hline & To an extent & $15(2.9 \%)$ & $12(2.3 \%)$ & $12(2.3 \%)$ & $30(5.8 \%)$ & $48(9.3 \%)$ & $117(22.6 \%)$ \\
\hline & Unaware & $33(6.4 \%)$ & $39(7.5 \%)$ & $21(4 \%)$ & $102(19.8 \%)$ & $195(37.8 \%)$ & $390(75.5 \%)$ \\
\hline & To an extent & $15(2.9 \%)$ & $12(2.3 \%)$ & $12(2.3 \%)$ & $30(5.8 \%)$ & $48(9.3 \%)$ & $117(22.6 \%)$ \\
\hline
\end{tabular}


Table 2:- Responses of study subjects based on their attitude towards dental health

\begin{tabular}{|c|c|c|c|c|c|c|c|}
\hline \multirow{2}{*}{$\begin{array}{l}\text { Questiona on attitude } \\
\text { to dental health }\end{array}$} & \multirow[t]{2}{*}{ Responses } & \multicolumn{5}{|l|}{ Specialities } & \multirow[t]{2}{*}{ Total } \\
\hline & & Diabetologist & Gynaecologist & Cardiologist & $\begin{array}{l}\text { Others } \\
\end{array}$ & None & \\
\hline \multirow{4}{*}{$\begin{array}{l}\text { What is your opinion } \\
\text { regarding the } \\
\text { relationship between } \\
\text { systemic and oral } \\
\text { diseases }\end{array}$} & $\begin{array}{l}\text { Systemic } \\
\text { diseases leads to } \\
\text { oral diseases }\end{array}$ & $6(1.1 \%)$ & $3(0.6 \%)$ & $3(0.6 \%)$ & $15(2.9 \%)$ & $33(6.4 \%)$ & $60(11.8 \%)$ \\
\hline & $\begin{array}{lr}\text { Oral } & \text { diseases } \\
\text { leads } & \text { to } \\
\text { systemic } & \\
\text { diseases } & \end{array}$ & 0 & $6(1.1 \%)$ & $9(1.7 \%)$ & $15(2.9 \%)$ & $51(9.9 \%)$ & $81(15.7 \%)$ \\
\hline & $\begin{array}{l}\text { It is a two way } \\
\text { process }\end{array}$ & $30(5.8 \%)$ & $39(7.5 \%)$ & $21(4 \%)$ & $102(19.8 \%)$ & $156(30.2 \%)$ & $348(67.4 \%)$ \\
\hline & $\begin{array}{l}\text { There is no } \\
\text { significant } \\
\text { relationship }\end{array}$ & $12(2.3 \%)$ & $3(0.6 \%)$ & 0 & $3(0.6 \%)$ & $9(1.7 \%)$ & $27(5.2 \%)$ \\
\hline \multirow{3}{*}{$\begin{array}{l}\text { Did you acquire any } \\
\text { knowledge about oral } \\
\text { diseases and its } \\
\text { relationship } \\
\text { systemic health while } \\
\text { you were in medical } \\
\text { college? }\end{array}$} & Yes & $30(5.8 \%)$ & $27(5.2 \%)$ & $18(3.4 \%)$ & $81(15.7 \%)$ & $162(31.4 \%)$ & $318(61.6 \%)$ \\
\hline & No & $9(1.7 \%)$ & $3(0.6 \%)$ & $3(0.6 \%)$ & $12(2.3 \%)$ & $33(6.4 \%)$ & $60(11.6 \%)$ \\
\hline & To an extent & $9(1.7 \%)$ & $21(4 \%)$ & $12(2.3 \%)$ & $42(8.1 \%)$ & $54(10.5 \%)$ & $138(26.7 \%)$ \\
\hline \multirow{3}{*}{$\begin{array}{l}\text { Do you feel that } \\
\text { medical training should } \\
\text { also include some } \\
\text { acquaintance about } \\
\text { screening of oral } \\
\text { diseases? }\end{array}$} & Yes & $27(5.2 \%)$ & $39(7.5 \%)$ & $24(4.6 \%)$ & $114(22 \%)$ & $180(34.9 \%)$ & $384(74.4 \%)$ \\
\hline & No & $9(1.7 \%)$ & $3(0.6 \%)$ & 0 & $9(1.7 \%)$ & $24(4.6 \%)$ & $45(8.7 \%)$ \\
\hline & To an extent & $12(2.3 \%)$ & $9(1.7 \%)$ & $9(1.7 \%)$ & $12(2.3 \%)$ & $45(8.7 \%)$ & $87(16.9 \%)$ \\
\hline \multirow{3}{*}{$\begin{array}{l}\text { Do you think oral } \\
\text { health evaluation } \\
\text { should be done by } \\
\text { general practitioners in } \\
\text { case of systemically ill } \\
\text { patients? }\end{array}$} & Yes & $30(5.8 \%)$ & $30(5.8 \%)$ & $24(4.6 \%)$ & $96(18.6 \%)$ & $171(33.1 \%)$ & $351(68 \%)$ \\
\hline & No & $12(2.3 \%)$ & $6(1.1 \%)$ & $3(0.6 \%)$ & $6(0.6 \%)$ & $27(5.2 \%)$ & $54(10.5 \%)$ \\
\hline & To an extent & $6(1.1 \%)$ & $15(2.9 \%)$ & $6(1.1 \%)$ & $33(6.4 \%)$ & $51(9.9 \%)$ & $111(21.5 \%)$ \\
\hline \multirow{3}{*}{$\begin{array}{l}\text { Is it necessary to } \\
\text { understand the } \\
\text { importance of the inter- } \\
\text { relationship between } \\
\text { systemic and oral } \\
\text { diseases and using the } \\
\text { knowledge for the } \\
\text { welfare of your } \\
\text { patients? }\end{array}$} & Yes & $30(5.8 \%)$ & $39(7.5 \%)$ & $33(6.3 \%)$ & $117(22.7 \%)$ & $213(41.3 \%)$ & $432(83.8 \%)$ \\
\hline & No & $3(0.6 \%)$ & $3(0.6 \%)$ & 0 & $6(1.1 \%)$ & $27(5.2 \%)$ & $39(7.5 \%)$ \\
\hline & To an extent & $15(2.9 \%)$ & $9(1.7 \%)$ & 0 & $12(2.3 \%)$ & $9(1.7 \%)$ & $45(8.7 \%)$ \\
\hline
\end{tabular}

Table 3:- responses of study subjects based on their practices on systemic conditions related to oral health

\begin{tabular}{|l|l|l|l|l|l|l|l|}
\hline \multirow{2}{*}{$\begin{array}{l}\text { Questions on } \\
\text { practices on systemic } \\
\text { conditions related to } \\
\text { oral health }\end{array}$} & Responses & \multicolumn{2}{|l|}{ Specialities } & Total \\
\cline { 3 - 8 } & & Diabetologist & Gynaecologist & Cardiologist & Others & None & \\
\hline $\begin{array}{l}\text { Do you enquire your } \\
\text { patients, if they had } \\
\text { any oral diseases now } \\
\text { or in the past? }\end{array}$ & Never & $6(1.1 \%)$ & $3(0.6 \%)$ & 0 & $3(0.6 \%)$ & $21(4 \%)$ & $33(6.3 \%)$ \\
\cline { 2 - 8 } & $\begin{array}{l}\text { Occasionally } \\
\text { frequently }\end{array}$ & $30(5.8 \%)$ & $36(6.9 \%)$ & $21(4 \%)$ & $93(18 \%)$ & $141(27.3 \%)$ & $321(62.2 \%)$ \\
\cline { 2 - 8 } & always & 0 & 0 & 0 & $9(1.7 \%)$ & $51(9.8 \%)$ & $72(13.9 \%)$ \\
\hline
\end{tabular}




\begin{tabular}{|c|c|c|c|c|c|c|c|}
\hline \multirow{4}{*}{$\begin{array}{l}\text { As medical } \\
\text { practitioners, do you } \\
\text { refer your patients to } \\
\text { the dentists for an } \\
\text { opinion about their } \\
\text { oral hygiene status? }\end{array}$} & Never & $9(1.7 \%)$ & $3(0.6 \%)$ & $6(1.1 \%)$ & $3(0.6 \%)$ & $33(6.3 \%)$ & $54(10.5 \%)$ \\
\hline & Occasionally & $30(5.8 \%)$ & $42(8.1 \%)$ & $24(4.6 \%)$ & $93(18 \%)$ & $120(23.2 \%)$ & $309(59.9 \%)$ \\
\hline & $\begin{array}{l}\text { Very } \\
\text { frequently }\end{array}$ & $6(1.1 \%)$ & 0 & 0 & $21(4 \%)$ & $66(12.7 \%)$ & $93(18 \%)$ \\
\hline & always & $3(0.6 \%)$ & $6(1.1 \%)$ & $3(0.6 \%)$ & $18(3.5 \%)$ & $30(5.8 \%)$ & $60(11.6 \%)$ \\
\hline \multirow{4}{*}{$\begin{array}{l}\text { Have you ever noticed } \\
\text { in your clinical } \\
\text { practice the systemic } \\
\text { manifestations of } \\
\text { periododntal diseases? }\end{array}$} & Never & $12(2.3 \%)$ & $6(1.1 \%)$ & $3(0.6 \%)$ & $15(2.9 \%)$ & $51(9.8 \%)$ & $87(16.8 \%)$ \\
\hline & Occasionally & $24(4.6 \%)$ & $45(8.7 \%)$ & $24(4.6 \%)$ & $105(20.3 \%)$ & $144(27.9 \%)$ & $342(66.2 \%)$ \\
\hline & $\begin{array}{l}\text { Very } \\
\text { frequently }\end{array}$ & $12(2.3 \%)$ & 0 & $66(12.8 \%)$ & $12(2.3 \%)$ & $54(10.5 \%)$ & $84(16.3 \%)$ \\
\hline & always & 0 & 0 & 0 & $3(0.6 \%)$ & 0 & $3(0.6 \%)$ \\
\hline \multirow{4}{*}{$\begin{array}{l}\text { In your point of view, } \\
\text { how often should a } \\
\text { patient go for dental } \\
\text { checkup? }\end{array}$} & Never & $6(1.1 \%)$ & 0 & 0 & $6(1.1 \%)$ & $33(6.3 \%)$ & $45(8.7 \%)$ \\
\hline & Occasionally & $12(2.3 \%)$ & $12(2.3 \%)$ & $12(2.3 \%)$ & $36(7 \%)$ & $93(18 \%)$ & $165(31.9 \%)$ \\
\hline & $\begin{array}{l}\text { Very } \\
\text { frequently }\end{array}$ & $18(3.4 \%)$ & $30(5.8 \%)$ & $18(3.4 \%)$ & $66(12.8 \%)$ & $93(18 \%)$ & $225(43.6 \%)$ \\
\hline & always & $12(2.3 \%)$ & $9(1.7 \%)$ & $3(0.6 \%)$ & $27(5.2 \%)$ & $30(5.8 \%)$ & $81(15.7 \%)$ \\
\hline \multirow{4}{*}{$\begin{array}{l}\text { Before any surgery, } \\
\text { do u recommend your } \\
\text { patients to go for a } \\
\text { dental checkup to rule } \\
\text { out focal sepsis }\end{array}$} & Never & $18(3.4 \%)$ & $21(4 \%)$ & $9(1.7 \%)$ & $21(4 \%)$ & $75(14.5 \%)$ & $144(27.9 \%)$ \\
\hline & Occasionally & $21(4 \%)$ & $27(5.2 \%)$ & $21(4 \%)$ & $87(16.8 \%)$ & $108(20.9 \%)$ & $264(51.1 \%)$ \\
\hline & $\begin{array}{l}\text { Very } \\
\text { frequently }\end{array}$ & $3(0.6 \%)$ & 0 & $3(0.6 \%)$ & $18(3.4 \%)$ & $27(5.2 \%)$ & $54(10.5 \%)$ \\
\hline & always & $6(1.1 \%)$ & 0 & $3(0.6 \%)$ & $18(3.4 \%)$ & $27(5.2 \%)$ & $54(10.5 \%)$ \\
\hline
\end{tabular}




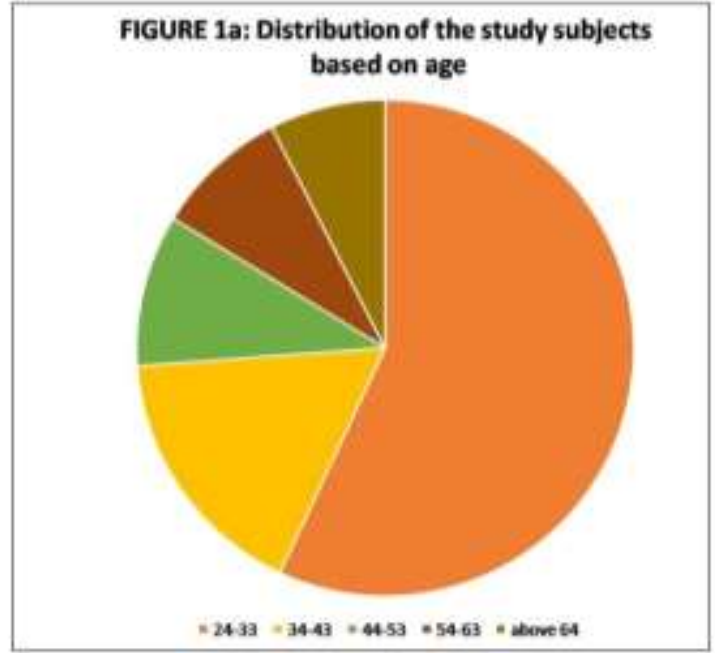

FIGURE 1C: Distribution of the study population according to the gender and qualification among males

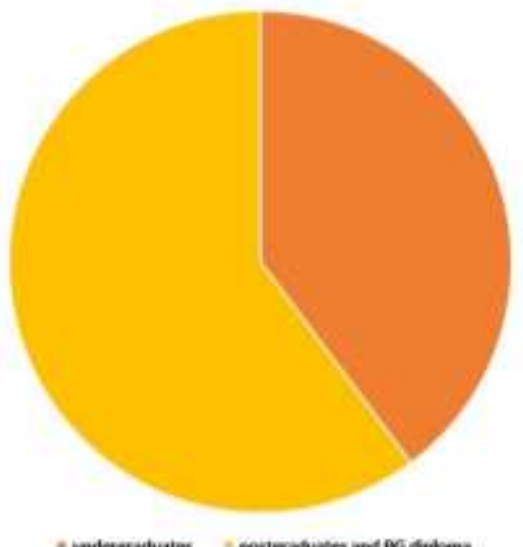

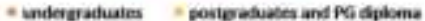

FIGURE 1e: Distribution of study population according to the gender and speciality among males

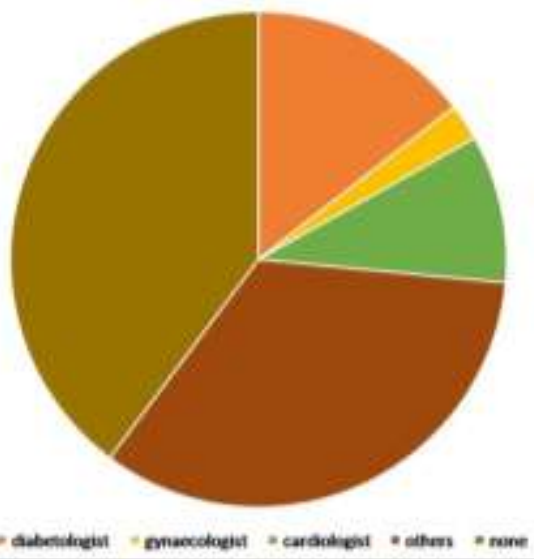

FIGURE 1b: Distribution of study subjects based on gender

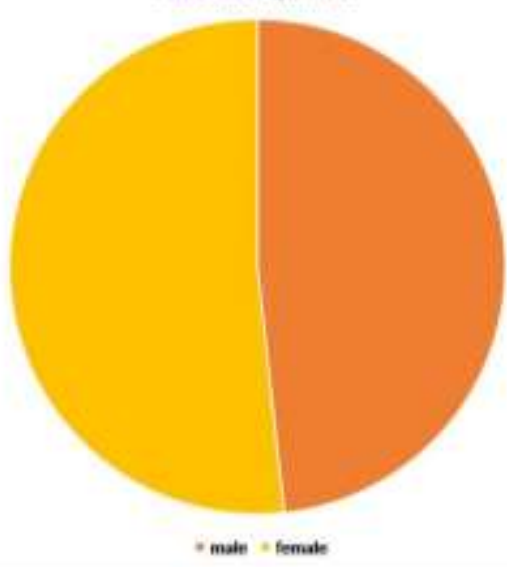

FIGURE 1d: Distribution of the study population according to the gender and qualification among females

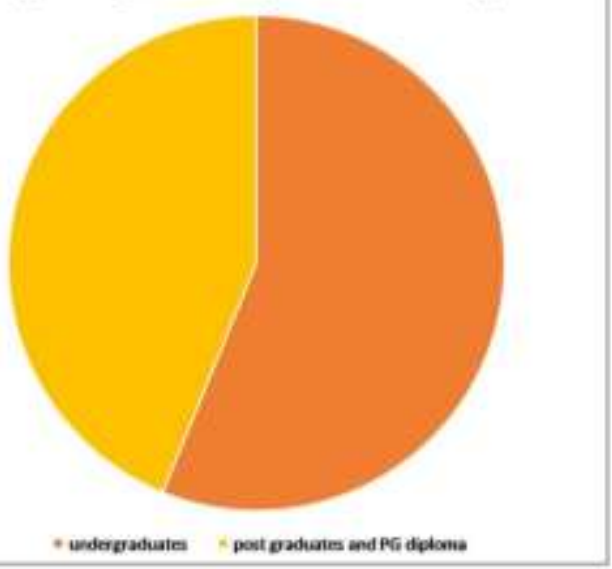

FIGURE 1f: Distribution of the study population according to gender and speciality among females

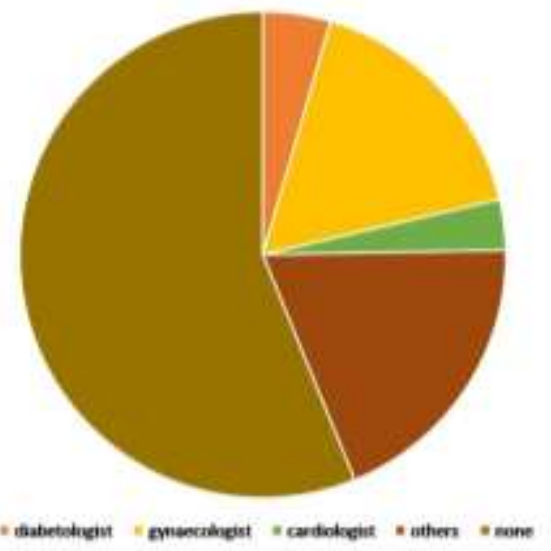



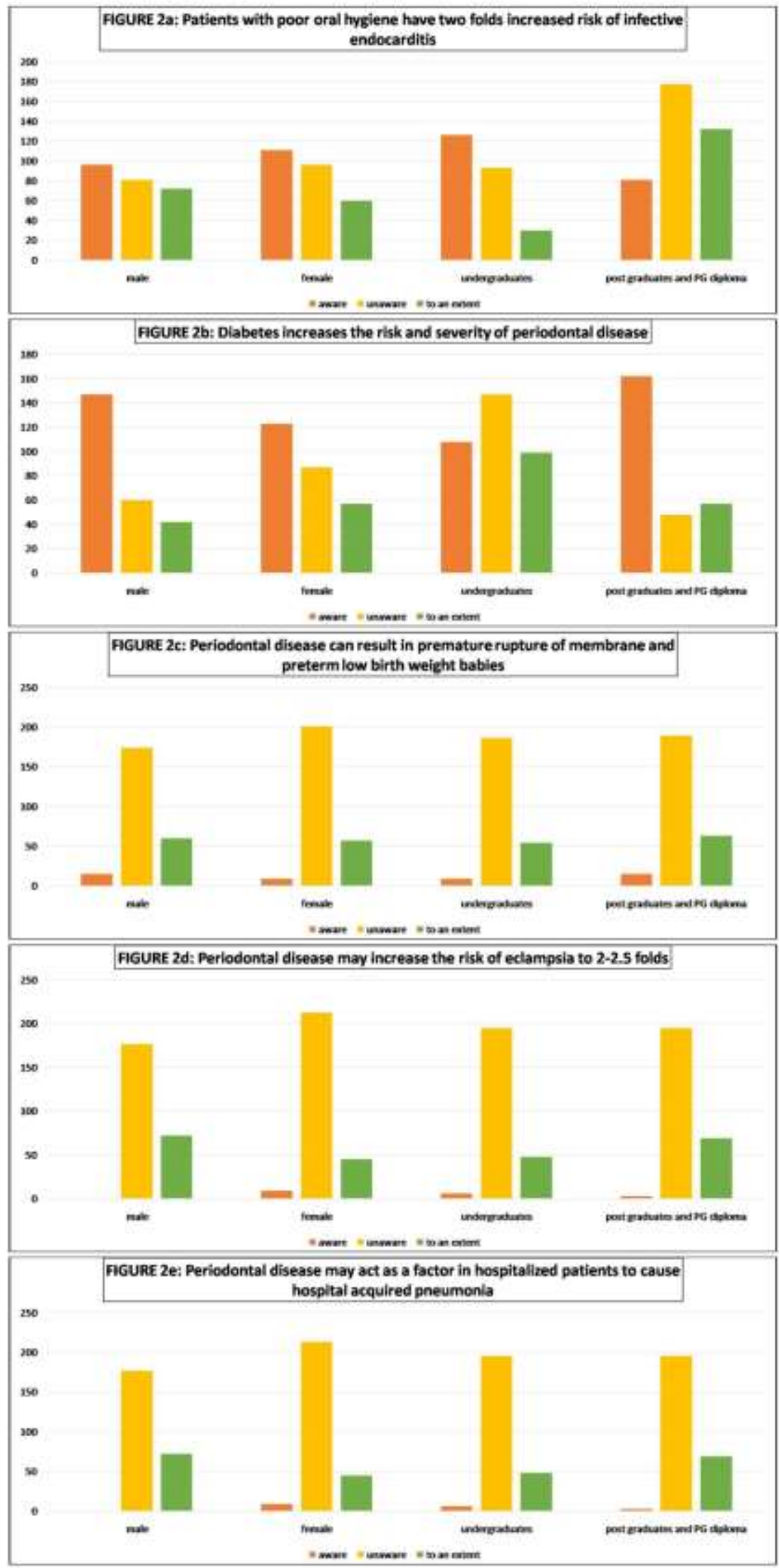


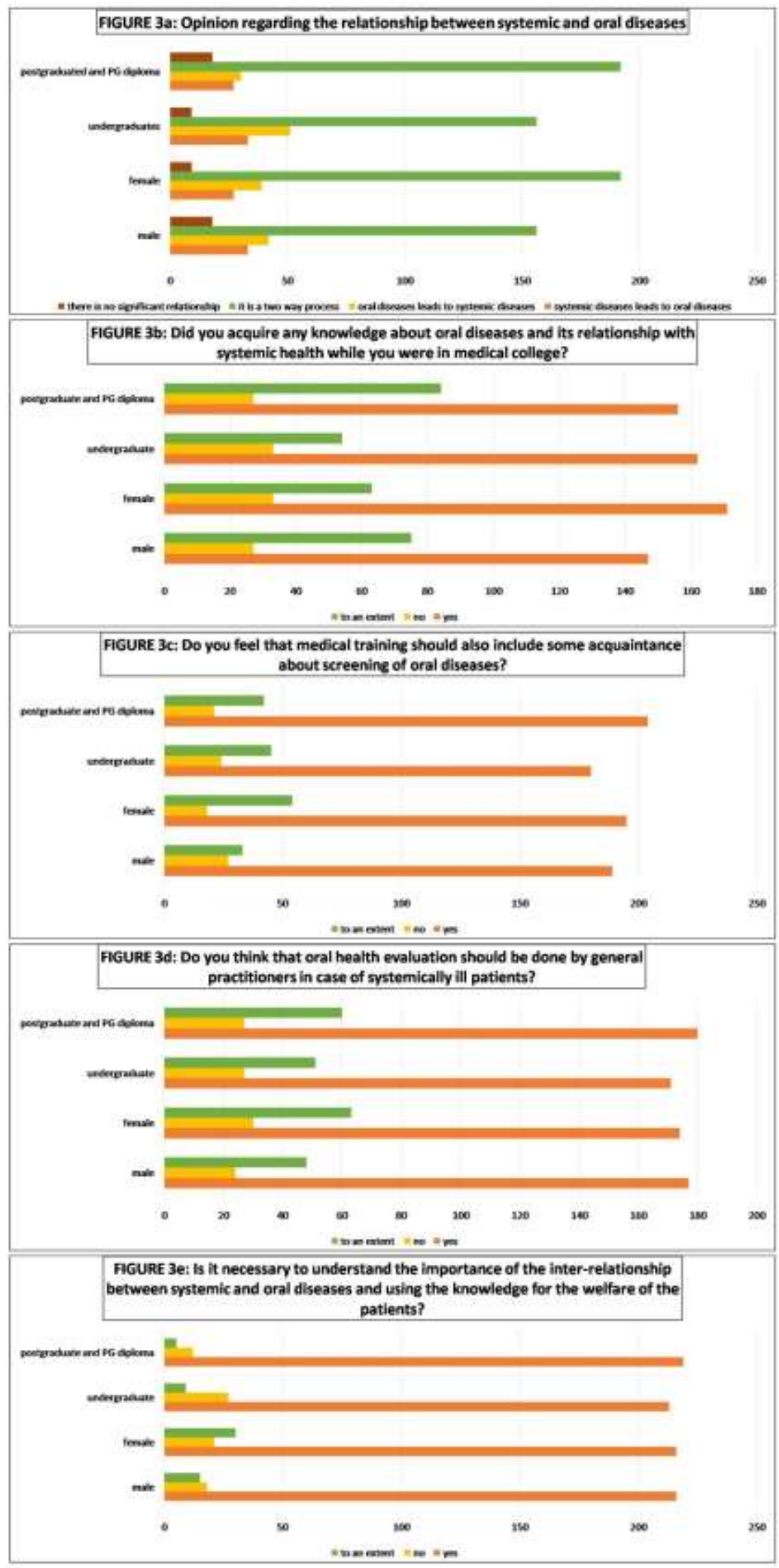



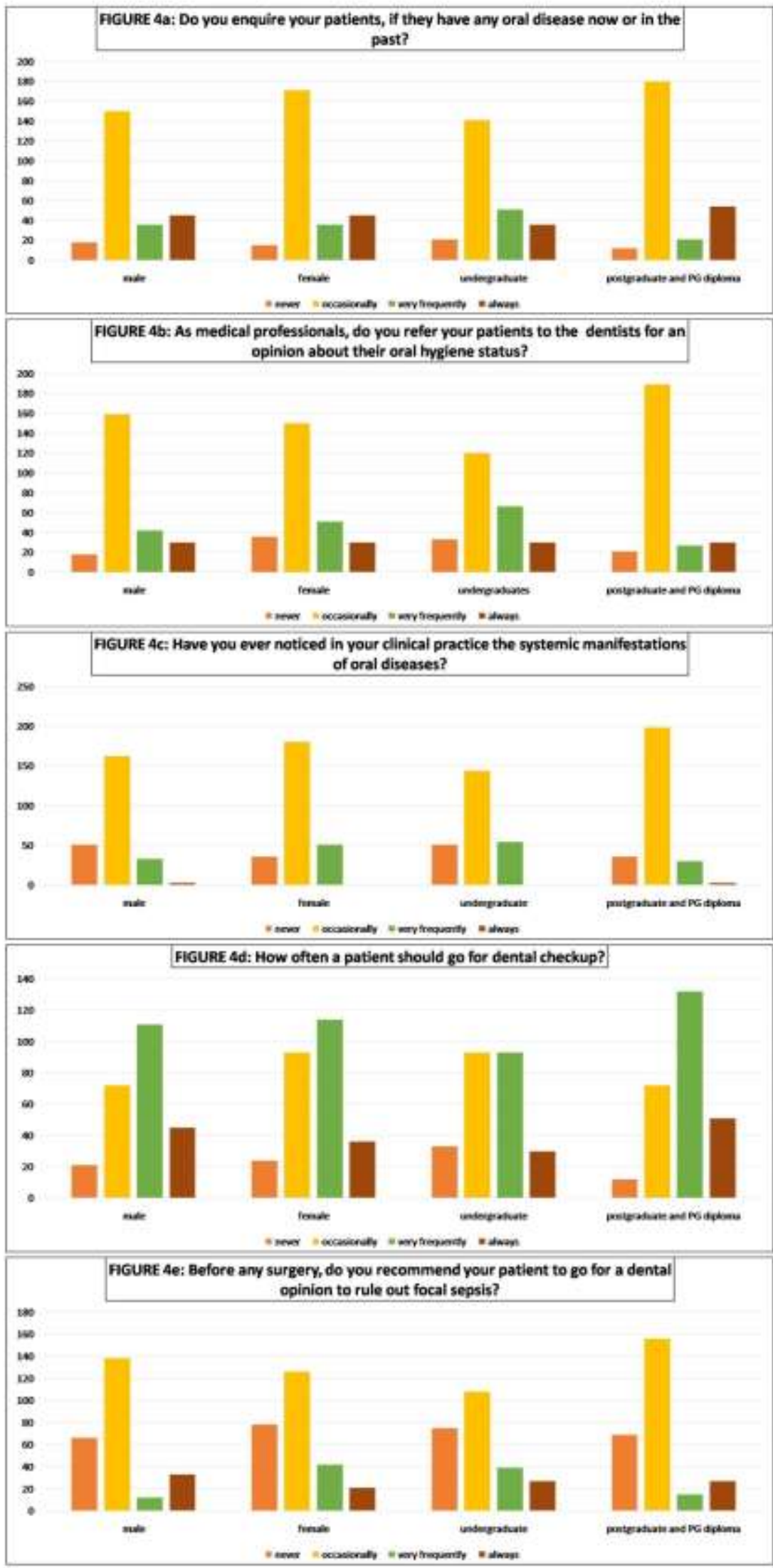


\section{References:-}

1. Asa'Ad, F., Al-Maflehi, N., Alelyan, B., Asaad, L., Alrumaih, W., Alassad, F., Alshakhs, S. and Alshakhs, B., 2014. Knowledge and orientations of medical interns toward periodontal disease in Saudi Arabia. Saudi Journal of Oral Sciences, 1(2), p.98.

2. Chandu, G.N., Prashant, G.M., Nagendra, J., Shafiulla, M. and Reddy, V.S., 2006. Dental Awareness and Attitudes of Medical Practitioners of Davangere City, Karnataka. Journal of Indian Association of Public Health Dentistry, 4(8), p.38.

3. Cheraskin, E., 1958. Oral manifestations of systemic diseases. Journal of the National Medical Association, 50(4), p.241.

4. Epstein, J.B., 1980. The mouth: a window on systemic disease. Canadian Family Physician, 26, p.953.

5. Gur, A. and Majra, J.P., 2009. Knowledge, attitude and practices regarding the systemic effects of oral diseases among the medical practitioners. Int J Dent Sci, 6(2), p.25.

6. Hämäläinen, P., Meurman, J.H., Kauppinen, M. and Keskinen, M., 2005. Oral infections as predictors of mortality. Gerodontology, 22(3), pp.151-157.

7. Madianos, P.N., Bobetsis, G.A. and Kinane, D.F., 2002. Is periodontitis associated with an increased risk of coronary heart disease and preterm and/or low birth weight births?. Journal of clinical periodontology, 29(s3), pp.22-36.

8. Mehrotra, V., Garg, K., Sharma, P., Sajid, Z. and Singh, R., 2015. A Study Based on Dental Awareness, Knowledge and Attitudes among the Medical Practitioners in and Around Kanpur City (India). J Interdiscipl Med Dent Sci, 3(183), p.2.

9. Moreu, G., Téllez, L. and González-Jaranay, M., 2005. Relationship between maternal periodontal disease and low-birth-weight pre-term infants. Journal of clinical periodontology, 32(6), pp.622-627.

10. Opeodu, O.I., Ogunrinde, T.J. and Fasunla, A.J., 2014. An assessment of medical doctors' perception of possible interrelationship between oral and general health. European Journal of General Dentistry, 3(2), p.120.

11. Patil, A.V., 2010. Awareness of Oral health among medical practitioners in Sangamner City-A cross-sectional survey. International Journal of Clinical Dental Science, 1(1).

12. Radha, G., Ali, K.S.H. and Pushpanjali, K., 2008. Knowledge, attitude and practice of oral health among nursing staff and nursing students of Bangalore city. Journal of Indian Association of Public Health Dentistry, 6(11), p.17.

13. Srinidhi, S., Ingle, N.A., Chaly, P.E. and Reddy, C., 2011. Dental awareness and attitudes among medical practitioners in Chennai. J Oral Health Comm Dent, 5(2), pp.73-78.

14. Syrjänen, J., Peltola, J., Valtonen, V., Iivanainen, M., Kaste, M. and Huttunen, J.K., 1989. Dental infections in association with cerebral infarction in young and middle-aged men. Journal of internal medicine, 225(3), pp.179-184.

15. Umino, M. and Nagao, M., 1993. Systemic diseases in elderly dental patients. International dental journal, 43(3), pp.213-218. 